\title{
Combination of a pesticide exposure and a bacterial challenge: In vivo effects on immune response of Pacific oyster, Crassostrea gigas (Thunberg)
}

\author{
Beatrice Gagnaire $^{\mathrm{a}}$, Melanie Gay ${ }^{\mathrm{b}}$, Arnaud Huvet ${ }^{\mathrm{c}}$, Jean-Yves Daniel ${ }^{\mathrm{c}}$, Denis Saulnier ${ }^{\mathrm{a}}$ and \\ Tristan Renault ${ }^{\mathrm{a},{ }^{*}}$
}

\begin{abstract}
alFREMER La Tremblade, Laboratoire de Génétique et Pathologie (LGP), 17390 La Tremblade, France, beatrice.gagnaire@free.fr, dsaulnier@ifremer.fr, trenault@ifremer.fr

${ }^{\mathrm{D}}$ AFSSA, Laboratoire d'Etudes et de Recherches sur les Produits de la Pêche, rue Huret Lagache, 62200 Boulogne sur Mer, France, m.gay@boulgone.afssa.fr

'UMR100 Physiologie et Ecophysiologie des Mollusques Marins, IFREMER Brest, BP 70, 29280

Plouzané, France, ahuvet@ifremer.fr, iydaniel@ifremer.fr

* Corresponding author: T. ReNAULT, LGP, 17390 La Tremblade, Tel: +33 5-46-76-26-49, Fax: +33 546-76-26-11, trenault@ifremer.fr
\end{abstract}

\begin{abstract}
:
To assess the impact of pollution induced by pesticides on Pacific oyster, Crassostrea gigas, health in France, in vivo effects of combined pesticide exposure and bacterial challenge on cell activities and gene expression in hemocytes were tested using flow cytometry and real-time PCR. As a first step, an in vivo model of experimental contamination was developed. Pacific oysters were exposed to a mixture of eight pesticides (atrazine, glyphosate, alachlor, metolachlor, fosetyl-alumimium, terbuthylazine, diuron and carbaryl) at environmentally relevant concentrations over a seven day period. Hemocyte parameters (cell mortality, enzyme activities and phagocytosis) were monitored using flow cytometry and gene expression was evaluated by real-time PCR (RT-PCR). The expression

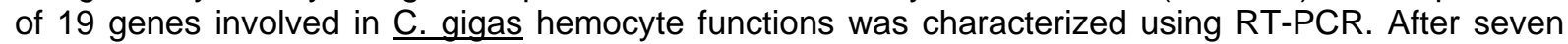
days of exposure, phagocytosis was significantly reduced and the 19 selected genes were downregulated in treated animals. As a second step, the experimental contamination method previously developed was used to study interactions between pesticide exposure and bacterial challenge by intramuscular injection of two Vibrio splendidus-related pathogenic strains. Oyster mortality and expression of 10 of the 19 selected genes were followed $4 \mathrm{~h}$ and $24 \mathrm{~h}$ post-injection. Oyster mortality was higher in pesticide-treated oysters compared to untreated oysters after the bacterial challenge. Gene expression was up-regulated in pesticide-treated oysters compared to untreated oysters after the bacterial challenge. We hypothesize that gene over-expression due to an interaction between pesticides and bacteria could lead to an injury of host tissues, resulting in higher mortality rates. In conclusion, this study is the first to show effects of pesticides at environmentally relevant concentrations on $\underline{C}$. gigas hemocytes and to hypothesize that pesticides modulate the immune response to a bacterial challenge in oysters.
\end{abstract}

\section{Keywords}

Pacific oyster, Crassostrea gigas; bivalve immunity; pesticides; hemocyte; phagocytosis; pathogenesis; Vibrio splendidus; flow cytometry; gene expression. 


\section{Introduction}

Shellfish exploitation is an historical world-wide activity and has intensified over the last century. The Pacific oyster, Crassostrea gigas, is the most frequently cultivated bivalve species and is typically reared in estuarine environments that have become increasingly threatened by exposure to pollutants. Among pollutants, pesticide contamination of shellfish has become more common in estuarine areas over the past several decades due, in part, to chemical run-off from terrestrial agriculture (Banerjee et al., 1996). Pesticides are introduced into rivers by ground "scrubbing" when rainfalls occur and then may enter marine areas, particularly estuarine and coastal zones. These pollutants may have major ecological consequences and could endanger organism growth, reproduction or survival (Banerjee et al., 1996).

Among physiological processes possibly disturbed by pollutants, the immune system is likely to be one of the more sensitive physiological systems (Fournier et al., 2000). The immune system contributes to host homeostasis by eliminating foreign particles (viruses, bacteria or parasites), killing abnormal cells and rejecting "non-self" components (Fournier et al., 2000). Pollutants or xenobiotics can interact with immune system components and interfere with protection functions and are therefore referred to as immunotoxics (Colosio et al., 2005). Xenobiotics can induce immunosuppression or stimulation, auto-immunity and decrease of disease resistance (Wong et al., 1992). In the past decades, the emergence of infectious diseases has been reported in marine species and disease outbreaks have also increased (Harvell et al., 1999). According to Snieszko (Snieszko, 1974), the development of an infectious disease results from an unbalance between the host and the pathogen due to external factors (including pollutants) and/or internal factors of both protagonists (virulence of the pathogen, susceptibility of the host). Animals presenting impaired defence mechanisms may be more susceptible to infectious diseases. Demonstration of the relationship between pollution and increase of susceptibility to infectious diseases exist in vertebrates. Harbour porpoises that died from infectious diseases presented a higher polychlorobiphenyl level than those that died from physical trauma (Jepson et al., 2005). Some studies have also attempted also to link contaminant presence and susceptibility to infectious diseases in bivalves. The bivalve defence system is mediated, in part, by hemocytes responsible for recognition, phagocytosis, and elimination by oxidation of non-self particles (Cheng, 1981). Several studies have demonstrated harmful effects of pollutants in bivalves, including PAHs (Wootton et al., 2003), PCBs (Canesi et al., 2003), pesticides (Alves et al., 2002) and heavy metals (Gagnaire et al., 2004) and in particular in the Pacific oyster, Crassostrea gigas (Gagnaire et al., 2006). Contamination of the eastern oyster, Crassostrea virginica, by polluted sediment and tributyltin increased the intensity of Perkinsus marinus infection, but no cellular or humoral parameters were modulated (Chu et al., 2002). In contrast, contamination of Mytilus edulis followed by a $\underline{\mathrm{V}}$. tubiashii challenge resulted in an increased hemocyte count when cadmium was used (Pipe and Coles, 1995) and in an increased phagocytosis with low concentrations of copper (Parry and Pipe, 2004). However, no clear relationship has been established between contaminants and immune

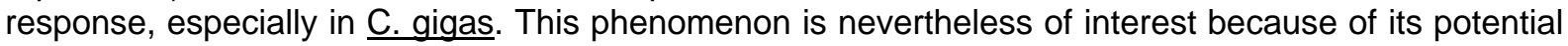
impact on the shellfish farming economy.

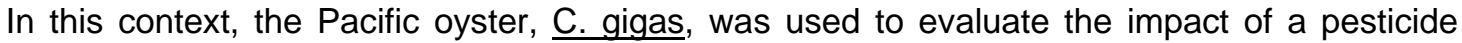
mixture on some immune-related capabilities in an economically important bivalve species and to demonstrate a relationship between infectious diseases, defence capacities and pollutants. In a previous study, we have demonstrated in in vitro assays the effect of a mixture of eight pesticides on phagocytosis on $\underline{C}$. gigas hemocytes, while none of these eight pesticides induced any effects when tested separately (Gagnaire et al., 2006). The aims of the present study were (i) to develop an in vivo model of experimental contamination using a mixture of pesticides similar to that used previously and representative of concentrations experienced in natural settings where oysters are cultured and (ii) to study effects of this mixture on the immune response to a bacterial challenge.

Oysters were exposed over a seven day period with a mixture of eight pesticides (atrazine, glyphosate, alachlor, metolachlor, fosetyl-alumimium, terbuthylazine, diuron and carbaryl). The pesticides were selected on the basis of spread amounts in the Marennes-Oleron Basin (CharenteMaritime, France), one of the most important oyster producing areas in France (Léonard, 2002; Munaron et al., 2006). As a first step, oysters were only contaminated in three distinct experiments and hemocyte biomarkers (cell mortality, esterase activity, production of Reactive Oxygen Species (ROS) and phagocytosis) were monitored using flow cytometry. The expression of 19 genes involved in hemocyte functions was also analysed using real-time PCR. In a second step, after a seven day contamination period, two pathogenic Vibrio splendidus-related_strains were simultaneously injected 
into the adductor muscle of oysters. Oyster mortality was daily monitored. The expression of ten genes among the 19 genes involved in hemocyte functions was followed after bacterial injection using realtime PCR. 


\section{Material and Methods}

\subsection{General Methods}

\subsubsection{Animals}

Pacific oysters, $\underline{C}$. gigas, with a shell height of $3-5 \mathrm{~cm}$, were produced and held at the IFREMER's laboratory in La Tremblade (Charente-Maritime, France) in February 2003. Analyses were performed from February 2004 to March 2005.

\subsubsection{Xenobiotics}

Eight pesticides were selected: atrazine, glyphosate, alachlor, metolachlor, fosetyl-alumimium, terbuthylazine, diuron and carbaryl (Promochem $\left.{ }^{\circledR}\right)$. A stock solution of each solid pesticide was separately prepared in an appropriate solvent (distilled water for glyphosate and terbuthylazine, $80 \%$ alcohol for the six other pesticides). The eight pollutant stock solutions were then each mixed in distilled water and $10 \mathrm{~mL}$ aliquots of this mixture was diluted in $1,990 \mathrm{~mL}$ of seawater to create a working solution. This working solution was prepared just before assays and 2,000 $\mathrm{mL}$ were added to individual experimental (contaminated) tanks $(100 \mathrm{~L})$. Oysters were only exposed to the mixture of eight pesticides. The final concentrations in tanks were: $0.7 \mu \mathrm{g} / \mathrm{L}$ for atrazine, $0.7 \mu \mathrm{g} / \mathrm{L}$ for glyphosate, $0.8 \mu \mathrm{g} / \mathrm{L}$ for alachlor, $0.6 \mu \mathrm{g} / \mathrm{L}$ for metolachlor, $0.6 \mu \mathrm{g} / \mathrm{L}$ for fosetyl-alumimium, $0.6 \mu \mathrm{g} / \mathrm{L}$ for terbuthylazine, $0.5 \mu \mathrm{g} / \mathrm{L}$ for diuron and $0.05 \mu \mathrm{g} / \mathrm{L}$ for carbaryl.

\subsubsection{Exposure protocol}

Experiments were conducted at IFREMER's laboratory in La Tremblade (Charente-Maritime, France). Oysters were acclimated over a one week period by increasing water temperature from $11-12^{\circ} \mathrm{C}$ to 19 $20^{\circ} \mathrm{C}$ using a thermostatic control $\left(1-2^{\circ} \mathrm{C}\right.$ increase per day). Seawater temperature was maintained at $19-20^{\circ} \mathrm{C}$ during the trial. Two tanks were used: One received 100 oysters in $100 \mathrm{~L}$ of seawater (untreated control) and one received 100 oysters in $100 \mathrm{~L}$ seawater added with pesticides (experimental treatment). Oysters were fed daily with Chaetoceros gracilis (addition of $10 \mathrm{~L}$ of phytoplankton solution at $5 \times 10^{6}$ cells $/ \mathrm{mL}$ in both tanks). Seawater was changed daily in both tanks. The pesticide solution was added every day after the seawater renewal in the experimental tank for seven days.

\subsubsection{Bacterial challenge}

Bacterial strains LGP31 and LGP32 (Vibrio splendidus-related) used in this study were isolated from oyster hemolymph during a mortality outbreak (Gay et al., 2004a). Both bacterial strains were separately grown at $20^{\circ} \mathrm{C}$ for $24 \mathrm{~h}$ in solid Zobell media that contained $2 \mathrm{~g}$ pastone, $0.5 \mathrm{~g}$ yeast extract, $6 \mathrm{~g}$ agar, $500 \mathrm{ml}$ of autoclaved $\left(121^{\circ} \mathrm{C}\right.$ for $20 \mathrm{~min}$ ) artificial seawater (ASW: $234 \mathrm{~g} \mathrm{NaCl}, 15 \mathrm{~g} \mathrm{KCl}, 12 \mathrm{~g}$ $\mathrm{MgSO}_{4} 7 \mathrm{H}_{2} \mathrm{O}, 2 \mathrm{~g} \mathrm{CaCl}_{2} 2 \mathrm{H}_{2} \mathrm{O}, 1$ I distilled water, use at $1 / 10$ dilution, $\mathrm{pH}=7.4$ ). After $24 \mathrm{~h}$, bacterial strains were maintained separately in $5 \mathrm{~mL}$ of liquid Zobell $(2 \mathrm{~g}$ pastone, $0.5 \mathrm{~g}$ yeast extract, $500 \mathrm{~mL}$ sterile $\mathrm{ASW}, \mathrm{pH}=7.4$ ) and cultivated with agitation for $24 \mathrm{~h}$ at room temperature. An equal volume of each bacterial suspension was collected and the two strains were mixed. Bacterial concentrations were evaluated using a spectrophotometer at $600 \mathrm{~nm}$ (UV-160, Shimadzuß). If the optical density value was 1.1, cell concentration was considered as $10^{9}$ Colony Forming Units (CFU). $\mathrm{ml}^{-1}$. Bacteria were centrifuged (30 min, 2,000 g) and re-suspended in ASW.

Before injection, oysters were anaesthetised by the addition of a $50 \mathrm{g.I}^{-1} \mathrm{MgCl}_{2}$ solution $\left(250 \mathrm{~g} \mathrm{MgCl}_{2}, 2\right.$ I seawater, 3 I freshwater) with phytoplankton (Isochrysis sp.) to stimulate feeding over a 2-3 h period with oxygenation. Subsequently, $50 \mu \mathrm{L}$ of the mixed bacterial strains were injected into the adductor muscle. After injection, oysters were maintained in tanks (30 oysters in $2.5 \mathrm{I}$ ) in aerated seawater filtered to $0.45 \mu \mathrm{m}$ at $20^{\circ} \mathrm{C}$. Animals were fed with phytoplankton daily.

These two Vibrio splendidus-related strains have a growth optimum of $19-20^{\circ} \mathrm{C}$. These strains were isolated from a mortality episode which occurred at similar temperatures. We, therefore, chose to conduct our bacterial challenge experiments at these temperatures.

\subsubsection{Hemocyte collection}

Hemolymph (0.5-1.0 mL) was collected from the pericardial cavity with the use of a 1-mL syringe equipped with a needle $(0.9 \times 25 \mathrm{~mm})$ after opening carefully the shell. Hemolymph samples were 
filtered through a $60 \mu \mathrm{m}$ mesh to eliminate aggregates and then maintained on ice to limit hemocyte aggregation for further_flow cytometry analysis and RNA extraction.

\subsubsection{Flow cytometry analysis}

Flow cytometry protocols were previously described (Gagnaire et al., 2006). For each sample, 3,000 events were counted using an EPICS XL 4 flow cytometer (Beckman Coulter). Results were analysed on cytograms indicating cell size (FSC value) and cell complexity (SSC value) with the fluorescence channel(s) corresponding to the marker used. A gate was defined on the basis of FSC value in order to eliminate cell debris and bacteria. Excitation was performed by an argon laser at $488 \mathrm{~nm}$.

Four hemocyte parameters (cell mortality, esterase activity, ROS production and phagocytosis) were monitored using flow cytometry. Analyses were conducted using $200 \mu \mathrm{L}$ of hemocyte suspension. For cell mortality, hemocytes were incubated in the dark for 30 minutes at $4^{\circ} \mathrm{C}$ with $10 \mu \mathrm{L}$ of propidium iodide (PI, $1.0 \mathrm{mg} . \mathrm{L}^{-1}$, Interchim); fluorescence emission was measured at $600 \mathrm{~nm}$. The EPICS XL 4 software allows differentiation between supposed populations of granulocytes and hyalinocytes based on FSC and SSC values. Esterase activity was measured using the non-specific liposoluble substrate fluoresceine diacetate (FDA, Molecular Probes). The non-fluorescent FDA diffuse in most of cells due to its liposoluble nature. Non-specific esterases hydrolyse it in a fluorescent product trapped in viable cells (Dive et al., 1990). One $\mu \mathrm{L}$ of a FDA solution $(400 \mu \mathrm{M})$ was added to $200 \mu \mathrm{L}$ of hemocyte suspension; fluorescence emission was measured at $514 \mathrm{~nm}$. Production of ROS was measured using dihydrorhodamine 123 (DHR123, Molecular Probes). DHR123 is a non-fluorescent reduced product derived from rhodamine 123. DHR 123 diffuses through cells and is oxidized in fluorescent rhodamine 123 by superoxide anion $\mathrm{O}_{2}{ }^{-}$during oxidative burst (Rothe et al., 1988). One $\mu \mathrm{L}$ of a DHR123 solution $(145 \mu \mathrm{M})$ was added to $200 \mu \mathrm{L}$ of hemocyte suspension; fluorescence emission was measured at 528 $\mathrm{nm}$. For esterase and ROS detection, cells were incubated for 30 minutes in the dark at room temperature and the reaction was stopped on ice (5 minutes). For esterase activity and ROS, gates were defined on cytograms in order to distinguish different populations according to fluorescence intensity and statistical analysis was only conducted on the population of strongly stained cells (Gagnaire et al., 2006). For phagocytic assay, $200 \mu \mathrm{L}$ of hemocyte suspension were incubated for $1 \mathrm{~h}$ in the dark at ambient temperature with $10 \mu \mathrm{L}$ of a $1 / 10$ dilution of Fluorospheres ${ }^{\circledR}$ carboxylatemodified microspheres (1 $\mu \mathrm{m}$ diameter, Interchim); fluorescence emission was measured at $515 \mathrm{~nm}$. Phagocytosis was measured as the proportion of cells that presented a fluorescent signal equal to or higher than the fluorescence of three beads as previously published (Gagnaire et al., 2006).

\subsubsection{Gene selection}

Nineteen genes involved in hemocyte functions were selected from $C$. gigas CDNA databases. Sixteen genes encode cell signalling proteins (ficolin, galectin, LBP/BPI and LPS/ $\beta-1,3$ glucan, Vav, importin $\alpha$, ECSIT, DOCK180 and C-Src kinase), cytoskeleton proteins (ankyrin, cofilin, filamin and Rho) and proteins involved in post-phagocytosis degradations and cellular protection mechanisms (Isocitrate dehydrogenase, proCL and SOD). Three other genes related to defence mechanisms in general were also monitored (Tissue Inhibitor of MetalloProteinases (TIMP), lysozyme and defensin) (Table 1).

\subsubsection{Total RNA extraction}

Total RNA was extracted from hemocytes using Trizol (Trizol ${ }^{\circledR}$ reagent, Invitrogen ${ }^{\mathrm{TM}} ; 1 \mathrm{ml}$ Trizol for $0,5-1 \cdot 10^{6}$ hemocytes) and treated with 1 unit DNase I (deoxyribonuclease) (Sigma) per $\mu g$ of total RNA to prevent DNA contamination. RNA concentrations were measured before and after DNase treatment at $260 \mathrm{~nm}$ using the conversion factor $1 \mathrm{OD}=40 \mu \mathrm{g}$ RNA.

\subsubsection{Reverse transcription}

Reverse transcription (RT) was carried out as previously described (Huvet et al., 2003) using oligo(dT)23 anchored as a primer, $200 \mathrm{U}$ moloney murine leukemia virus (MMLV) reverse transcriptase (Sigma), and $2 \mu \mathrm{g}$ of total RNA PCR samples from each condition.

\subsubsection{Real-time PCR analysis}

The relative levels of gene transcripts in untreated $(U)$ and pesticide-treated $(T)$ oysters were investigated by real-time PCR using an Icycler (Bio-Rad Laboratories Inc.). Amplification of a specific cDNA (elongation factor, coefficient of variation $<5 \%$ ) was performed to confirm the steady-state 
expression of a housekeeping gene, allowing an internal control for gene expression. Primer sequences and GenBank accession numbers for all studied and housekeeping genes are reported in Table 2. Real-time PCR was performed in triplicate in a total volume of $15 \mu \mathrm{L}$ with $5 \mu \mathrm{L}$ of cDNA $(1 / 10$ dilution), $0.5 \mu \mathrm{L}$ of each primer (final concentration of $0.33 \mu \mathrm{M}$ ), $1.5 \mu \mathrm{L}$ distilled water and $7.5 \mu \mathrm{L}$ of $2 \mathrm{X}$ "iQ ${ }^{\mathrm{TM}}$ SYBR® Green supermix" (BioRad). The cycling conditions consisted Taq polymerase thermal activation for $3 \mathrm{~min}$ at $95^{\circ} \mathrm{C}$, then 40 cycles of denaturation at $95^{\circ} \mathrm{C}$ for $30 \mathrm{~s}$ and annealing/elongation at $60^{\circ} \mathrm{C}$ for $1 \mathrm{~min}$. For each individual sample, a melting curve program was carried out from $95^{\circ} \mathrm{C}$ to $55^{\circ} \mathrm{C}$ by decreasing temperature by $0.5^{\circ} \mathrm{C}$ each $10 \mathrm{~s}$ in order to confirm production of a single product. Each run included the cDNA control, negative controls (total RNA treated with DNase I) and blank controls (distilled water). PCR efficiency (E) was determined for each primer pair by performing standard curves from serial dilutions to ensure that $E$ ranged from $99 \%$ to $100 \%$. Cycle threshold $(\mathrm{Ct})$ value corresponded to the number of cycles at which the fluorescence emission monitored in real-time exceeded the threshold limit. Ct and E were determined using the iCyclerTMiQ, Optical System Software, v. 3.0a (BioRad). The relative expression ratio of each gene was calculated using REST-384 (C) software (Relative Expression Software Tool, http://www.gene-quantification.de/rest-384.html) (Pfaffl et al., 2002). The relative expression ratio for a considered gene is based on the PCR efficiency $(E)$ and the $\mathrm{Ct}$ of the pesticide treated $(\mathrm{T})$ sample versus the untreated $(\mathrm{U})$ sample expressed in comparison to the reference gene, according to Pfaffl's mathematical model (Pfaffl, 2001):

$$
\text { Ratio }=\frac{(E \text { studied gene })^{\Delta C t \text { studied gene (untreated-treated) }}}{(E \text { reference gene })^{\Delta C t \text { reference gene (untreated-treated) }}}
$$

\subsection{Schedule of trials}

\subsubsection{Pesticide contamination}

The contamination experiment was distinctly performed three times during February and March 2004. Flow cytometry analyses were performed for these three experiments to assess the four hemocyte parameters outlined in the general methods section above. At days 1, 3 and 7 after pesticide contamination, hemocytes from 20 oysters per condition (untreated $(U)$ and treated $(T)$ ) were collected. Twenty untreated oysters were also analysed at Day 0 (before adding pesticides). For both conditions $(\mathrm{U}$ and $\mathrm{T})$, hemolymph from four pools of five oysters were used to reduce inter-individual variation and to provide enough hemocytes. Pooled hemocytes were counted on a Malassez cell and were adjusted to $10^{6}$ cells. $\mathrm{mL}^{-1}$ with ASW. After seven days of contamination for the first experiment, hemolymph from 20 oysters per condition ( $U$ and $\mathrm{T}$ ) were collected and pooled for RNA extraction and characterization of gene expression using real-time PCR analysis of the 19 selected genes (Table 1).

\subsubsection{Bacterial injection}

Experiments were run in January 2005 without pesticide contamination in order to define the mortality percentages induced by different concentrations of LGP31+LGP32 Vibrio strains in control (without pesticides) oysters. Equal concentrations of each strain were inoculated into oysters (total concentrations of $2.10^{8}, 4.10^{7}$ and $4.10^{6} \mathrm{CFU} /$ oyster). Experiments were carried out three times for each bacterial concentration and two replicates were employed in each of the three conditions (injected with $2.10^{8}, 4.10^{7}$ and $4.10^{6} \mathrm{CFU} /$ oyster). Oyster mortality percentages were recorded for each bacterial concentration at several post-injection times ( $2 \mathrm{~h}, 4 \mathrm{~h}, 24 \mathrm{~h}, 48 \mathrm{~h}, 72 \mathrm{~h}, 120 \mathrm{~h}, 144 \mathrm{~h}$ and $168 \mathrm{~h})$.

\subsubsection{Pesticide contamination followed by bacterial injection}

In order to observe the impact of pesticide contamination on oyster sensitivity to bacterial disease, exposure to the pesticide mixture was followed by a bacterial injection trial in March 2005. After a contamination period of seven days as outlined above, treated oysters as well as untreated oysters were injected with $4.10^{7} \mathrm{CFU} /$ oyster. Negative controls consisted of ten oysters ( $\mathrm{U}$ and $\mathrm{T}$ ) that were injected with sterile ASW. Oyster mortality was monitored for each of the four conditions (U injected with ASW, T injected with ASW, $U$ injected with $4.10^{7}$ CFU/oyster, T injected with $4.10^{7}$ CFU/oyster) at several times post-injection $(2 \mathrm{~h}, 4 \mathrm{~h}, 24 \mathrm{~h}, 48 \mathrm{~h}$ and $72 \mathrm{~h})$. Two replicate tanks were included for each of the four conditions. This experiment was realised one time. 
Hemolymph from ten oysters for the four conditions were collected $4 \mathrm{~h}$ and $24 \mathrm{~h}$ post-injection for RNA extraction and gene expression analysis. In this trial, the expression of ten genes was followed by realtime PCR: ficolin, galectin and LBP/BPI, C-Src kinase, ankyrin, proCL, SOD, TIMP, lysozyme and defensin (Table 1).

Statistical analysis. For flow cytometry analysis, results were expressed as percentage of positive cells. Results were expressed as percentages for mortality measurements. Values were arcsine square root transformed to achieve normality. ANOVAs were carried out using Statgraphics ${ }^{\circledR}$ Plus version 5.1 software. Significance was set at $p \leq 0.05$.

For real-time PCR analysis, statistical differences in gene expression between conditions were evaluated in group means by randomisation tests (Pfaffl et al., 2002) using REST-384 (C) software and Pair Wise Fixed Reallocation Randomisation Test@. Two thousand random allocations were performed and significant differences were considered at $p<0.05$.

\section{Results}

\subsection{Effects of pesticide exposure on oysters}

\subsubsection{Hemocyte parameters}

No oyster mortality was reported in any of the three experiments (data not shown). Cell mortality, esterase and ROS production showed no significant differences between $U$ (untreated oysters) and $T$ (treated oysters) (Erreur! Source du renvoi introuvable.). Phagocytosis was significantly lower in T compared to $U$ (i) after seven days of contamination for experiment 1 , one and seven days for experiment 2, and 3 and seven days for experiment $3(p<0.05$, Erreur! Source du renvoi introuvable.), (ii) for the whole data treated independently of time for each experiment and (iii) after seven days of contamination when pooling data of the three experiments (data not shown).

\subsubsection{Gene expression}

Relative expression of the 19 selected genes involved in hemocyte functions was significantly lower for all genes from treated $(T)$ compared to those from untreated $(U)$ animals $(p<0.001$, Erreur ! Source du renvoi introuvable.). Decreases in gene expression of T compared to $U$ ranged from 60.8 $\%$ for defensin (2.5 times lower) to $96.9 \%$ for filamin (32.6 times lower) (Erreur ! Source du renvoi introuvable.).

\subsection{Effects of bacterial challenge on oyster mortality}

The injection of $4.10^{7}$ CFU/oyster induced $55 \pm 8.8 \%$ of mortality at $168 \mathrm{~h}$ post-injection (Erreur ! Source du renvoi introuvable.). Injection of $4.10^{6} \mathrm{CFU} /$ oyster induced significantly lower mortalities relative to other concentrations: mortality percentage was $20 \pm 10.5 \% 168 \mathrm{~h}$ post-injection (Erreur ! Source du renvoi introuvable.). Injection of $2.10^{8} \mathrm{CFU} /$ oyster induced the highest mortality: mortality rates were $23.3 \pm 6 \%$ and $90 \pm 2.6 \%$ at $2 \mathrm{~h}$ and $168 \mathrm{~h}$ post-injection, respectively (Erreur ! Source du renvoi introuvable.).

\subsection{Combined effects of pesticide exposure and bacterial challenge on oysters}

Preliminary experiments using only bacteria showed that $2.10^{8} \mathrm{CFU} /$ oyster, induced high losses $24 \mathrm{~h}$ post-injection. In contrast, $4.10^{6} \mathrm{CFU} /$ oyster induced low mortality. Both bacterial concentrations were not selected for further studies because pesticide effects on mortality would have been difficult to detect under very high or low mortality conditions. The concentration of $4.10^{7} \mathrm{CFU} /$ oyster was selected to carry out assays including pesticide contamination and a bacterial challenge.

\subsubsection{Mortality}

After bacterial inoculation, mortality was significantly higher for treated oysters ( $T$ ) compared to untreated oysters $(U)$ at $48 \mathrm{~h}, 72 \mathrm{~h}$ post exposure and when cumulative mortality was examined (three way ANOVA, $F=19.62, p=0.0001$, Erreur ! Source du renvoi introuvable.). Seventy percent $( \pm 5$ $\%$ ) of T injected with $4.10^{7}$ CFU/oyster died by $72 \mathrm{~h}$ post-injection, while only $25 \pm 3.7 \%$ of $U$ injected with the same dose died (Erreur ! Source du renvoi introuvable.). At $24 \mathrm{~h}$ post-injection, mortality rates were not significantly different between pesticide $T$ and $U$ injected with bacteria $(p>0.05$, Erreur ! 
Source du renvoi introuvable.). A few of control oysters, T or U injected with ASW, died during this trial ( $8 \%$ of cumulative mortality $72 \mathrm{~h}$ post-injection) and values were not significantly different between $\mathrm{T}$ and $\mathrm{U}$ (Erreur ! Source du renvoi introuvable.). Mortality was highest at $72 \mathrm{~h}$ post-injection in all conditions ( $F=50.75, p=0$, Erreur ! Source du renvoi introuvable.).

\subsubsection{Gene expression}

In our experiments, gene expression from pesticide treated animals injected with ASW or bacteria were compared to untreated animals injected with ASW or bacteria. Our experiment design allowed to follow pesticide effects, and not bacterial effects alone, on gene expression after a bacterial challenge. We monitored the expression of only ten of the 19 genes followed in pesticide contamination experiments (Table 1). We had to make a selection because of the limited quantity of RNA extracted from hemocytes for these experiments. We monitored gene expression $4 \mathrm{~h}$ and $24 \mathrm{~h}$ post-injection because mortality rates were not significantly different between treated injected oysters and untreated injected oysters. Samples at this time were therefore comparable.

Experimental treatments impacted gene expression. Both down and up-regulation was observed.

(i) When injected with seawater, the relative expression of five genes (galectin, C-Src kinase, ankyrin, lysozyme and defensin) was down-regulated in pesticide treated oysters (T) compared to untreated oysters $(U) 4 h$ post-injection $(1.9,2.7,1.8,1.7$ and 2.6 times lower, respectively, $p<0.05$, Erreur ! Source du renvoi introuvable.). The relative expression of three genes (ficolin, SOD and TIMP) increased 24h post-injection of ASW (3.0, 4.6 and 2.4 times higher, respectively, $p<0.05$,Erreur ! Source du renvoi introuvable.).

(ii) When injected with bacteria, the relative expression of ficolin, galectin, C-Src kinase, ankyrin, SOD, lysozyme and defensin decreased in T compared to $U$ 4h post-injection of $4.10^{7}$ CFU/oyster $(8.9,6.6$, 9.1, 3.3, 4.4, 23.6 and 2.2 times lower, respectively, $\mathrm{p}<0.05$, Erreur! Source du renvoi introuvable.). The expression of the ten genes (ficolin, galectin, LBP/BPI, C-Src kinase, ankyrin, proCL, SOD, TIMP, lysozyme, defensin) was up-regulated $24 \mathrm{~h}$ post bacterial injection $(3.8,3.9,3.4$, $3.4,2.1,6.3,2.5,3.5,2.6$ and 2.9 times higher, respectively, $p<0.05$, Erreur! Source du renvoi introuvable.). Among these ten genes, the expression of seven genes (galectin, LBP/BPI, C-Src kinase, ankyrin, proCL, lysozyme and defensin) was not changed 24h after ASW injection. Results are summed up on Table 3. 


\section{Discussion}

Although often employed in successful modern agriculture, the use of pesticides leads to severe environmental pollution and can be dangerous for human safety. Dangerous amounts of pesticides and pesticide residues have been found in vegetables, milk and meat (Banerjee et al., 2001). The effects of pesticides have been evaluated most commonly by quantifying enzymatic alterations, and pathological, carcinogenic and mutagenic effects. Despite the intensive use of pesticide in coastal areas, few studies have investigated their effects on marine animals in laboratory trials (Galloway and Depledge, 2001) and have focused primarily on the effects of pesticide mixtures (Faust et al., 2001; Tanguy et al., 2005; Gagnaire et al., 2006). Although animals are exposed to complex mixtures of pollutants in the environment, most of laboratory experiments are based on the use of a unique pollutant (Banerjee et al., 2001). Studies on herbicides (Faust et al., 2001) have shown some positive interactions: toxicity of a mixture of pollutants was higher than the toxicity of individually tested chemicals. A pesticide mixture modulated $\underline{C}$. gigas hemocyte phagocytosis in vitro whereas no modulation was reported for each molecule tested individually (Gagnaire et al., 2006). Antagonist effects have also been shown for heavy metals (Breittmayer et al., 1984).

\subsection{Effects of pesticides on hemocyte parameters and defence gene expression}

Although cell mortality, esterase and ROS activity were not modified by the pesticide mixture, phagocytic ability decreased after three and seven days of contact in the three experiments. Some of the selected pesticides present in the mixture have already been tested individually on phagocytosis in in vivo assays. Atrazine decreased phagocytosis in Lymnaea stagnalis (Russo and Lagadic, 2004) but had no effect on that activity in $\underline{C}$. gigas (Gagnaire et al., 2003). Diuron increased phagocytosis of $\underline{C}$. gigas hemocytes after 4 weeks of exposure (Bouilly et al., 2007). The combined effects of these molecules affected phagocytosis in $\underline{\mathrm{C} \text {. gigas. }}$

The expression of all 19 genes monitored by real-time PCR in the present study showed a decrease in mRNA levels in samples exposed to pesticides compared to untreated samples. These results support the observed decrease in phagocytosis activity reported using flow cytometry after three and seven days of contamination; some of these genes are involved in defence mechanisms and phagocytosis process. Indeed, ficolin-3 and galectin- 4 are two lectins that bind $\beta$-galactoside residus (Mitta et al., 2005). LBP/BPI complex and LGBP bind LPS and activate the pro-phenoloxidase cascade (Mitta et al., 2005). LGPB is over-expressed upon bacterial infections (Tanguy et al., 2004) and was overexpressed in $\mathbf{C}$. gigas after 30 days of contamination with a mixture of atrazine, diuron and isoproturon (Tanguy et al., 2005). Our results, in contrast, showed a down-regulation of these genes. Isoproturon was not used in our experiments and concentrations of other molecules were lower than in the study by Tanguy et al. (2005). Vav-3 protein, cofilin and importin- $\alpha$ are involved in signal cascade of lymphocytes in vertebrates (Lee et al., 2000; Andrade et al., 2003; Fujikawa et al., 2003). DOCK180 protein and c-Src kinase are involved in macrophage activation (Suzuki et al., 2000; Cote and Vuori, 2002). ECSIT is involved in the Toll/IL-1 and Rel/NF-KB signal cascade, important in innate immune response to infectious agents by the regulation of MAPK (Kopp et al., 1999), which exists in bivalves (Canesi et al., 2002). Our experiments showed a down-regulation of these six genes which, suggest a disruption of cell activation pathways, and may be related to the reduced phagocytic ability observed in the present study. Ankyrin is important in cytoskeleton organisation (Lambert and Bennett, 1993). Filamin, an actin binding protein, and Rho protein, a GTPase, are involved in the regulation of actin organisation and adhesion (Chimini and Chavrier, 2000; Van der Flier and Sonnenberg, 2001). In our study, these three genes were down-regulated by pesticides exposure, which could modify cytoskeleton activities and render hemocytes unable to phagocytose particles. Isocitrate dehydrogenase and SOD protect cells against reactive oxygen species (Kim and Park, 2003). We showed a down-regulation of these both genes, which could lead to a decrease of protection against free radicals, one of the known action mode of several pesticides (Banerjee et al., 2001). However, no modification of ROS production monitored by flow cytometry was found after the pesticide exposure (Erreur ! Source du renvoi introuvable.). Cathepsin $L$ is present in lysosomes and is involved in protein degradation (Hu and Leung, 2004). Our results showed a down-regulation of this gene by pesticides which could lead to a decrease of post-phagocytosis degradations. However, cathepsin $L$ over-expression has been observed in oysters contaminated with glyphosate after 30 days of contamination (Tanguy et al., 2005). TIMP is a protease inhibitor over-expressed after injuries and

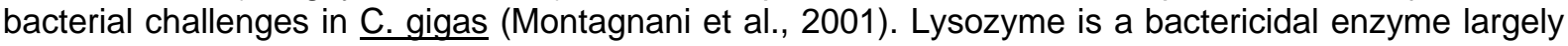
present in bivalves (Cheng, 1981). Defensin is an anti-bacterial peptide (Gueguen et al., 2006). These 
genes were down-regulated in our experiments. Pesticides may lead to decrease of bactericidal activities.

The down-regulation of these 19 genes by pesticides may therefore decrease oyster capacity to respond to an infectious agent.

\subsection{Effects of pesticides and bacterial injection on oyster mortality and gene expression}

Vibrio splendidus-related strains (LGP31+LGP32) used in this study were previously isolated from moribund oysters during a mortality episode. These bacteria induced a higher mortality when injected simultaneously than when inoculated separately (Gay et al., 2004a). Intramuscular injection was selected in the present study to induce high mortality rates ( $50 \%)$ (Gay et al., 2004a). This technique by-passes first lines of defence. Although bath exposure using the same bacterial strains induced mortality, losses were lower than via injection with high variations between experiments (Gay et al., 2004b).

The present study provides the first demonstration of the effects of a pesticide mixture at environmentally relevant concentrations on $\underline{C}$. gigas exposed to a bacterial challenge. After the bacterial challenge, mortality rates in pesticide treated animals were higher than in untreated animals at $48 \mathrm{~h}$ and $72 \mathrm{~h}$ post-injection, indicating that pesticide exposure increased oyster susceptibility to the bacterial injection. Chou et al. (Chou et al., 1998) previously demonstrated an interaction between heavy metal exposure and viral infection in the Oriental calm, Meretrix lusoria. Higher losses were observed in $\underline{\mathrm{M}}$. lusoria contaminated with heavy metals and exposed to a birnavirus relative to animals that were exposed to single stressors (heavy metals or birnavirus).

An increase of the expression of the ten selected genes was reported $24 \mathrm{~h}$ after the bacterial challenge in pesticide treated oysters. However, three of these ten genes (ficolin, TIMP and SOD) were also upregulated $24 \mathrm{~h}$ after ASW injection. We could hypothesize that the up-regulation of these three genes is due to the mechanical aggression due to injection. The higher expression of the seven other genes (galectin, LBP, C-Src kinase, ankyrin, proCL, lysozyme, defensin) could be first interpreted as a more efficient defence response of the oysters to the bacterial injection. Up-regulation of these genes was reported in invertebrates and vertebrates during the course of infectious diseases (Montagnani et al., 2001; Ge et al., 2004; Allam et al., 2006). However, higher mortality rates were reported in pesticide treated injected oysters compared to untreated injected oysters at $48 \mathrm{~h}$ and $72 \mathrm{~h}$ post-injection. Moreover, high expression of some of these seven genes observed during the course of infectious diseases has been demonstrated to correlate with host damage in vertebrates. High levels of cathepsins B, D and $L$ were observed after a Pseudomonas aeruginosa infection in mice and resulted in corneal lesions (Dong et al., 2001). In another study, defensin concentrations were higher in human patients infected with lung diseases than in healthy human patients and have been demonstrated to contribute to disease pathogenesis (Ashitani et al., 1998). In vertebrates, when mechanisms initially developed for the host defence are not correctly controlled, these complex defence mechanisms could create pathological disorders (Haslett et al., 1989).

Pesticides modified the oyster response to a bacterial challenge by inducing an up-regulation of genes involved in hemocyte functions. Some of these genes are involved in defence mechanisms. We could therefore expect that oyster would present higher defence capacities and therefore reduced disease susceptibility. However, by analogy with vertebrates, and considering the fact that oyster mortality was higher in treated animals compared to untreated animals after the bacterial challenge, we therefore hypothesize that this up-regulation of defence genes could become harmful for the host by causing tissue damages and could be associated to pathogenesis of the disease. Pesticides could modify the regulation capacity of the response to infectious agents in oysters. To support this concept and to substantiate correlation among over-expression of genes and host damage, some tissue morphohistological observations are needed.

\section{Conclusion}

This study showed that a pesticide mixture used on Pacific oyster, $\underline{C}$. gigas, in laboratory conditions at environmentally relevant concentrations (i) decreased hemocyte phagocytosis in a reproducible way, (ii) down-regulated genes involved in hemocyte functions, particularly phagocytosis, and (iii) increased susceptibility to a bacterial challenge. This is the first study to combine two different techniques (flow cytometry and real-time PCR) to study the effects of pollutants on defence mechanisms in Pacific 
oyster, C. gigas, and to demonstrate, at molecular level, a link between defence system, pesticide and susceptibility to pathogenic bacteria in oysters. However, our results were obtained using an experimental model of infection based on intramuscular injection of bacteria. This could be useful to reproduce these experiments in conditions closer of those encountered in natural infection (bath exposure). Our study showed that Galectin, LBP, C-Src kinase, ankyrin, proCL, lysozyme and defensin may be considered as markers of a bacterial infection and could be involved in disease pathogenesis. These experiments allowed establish a reproducible model of contamination and

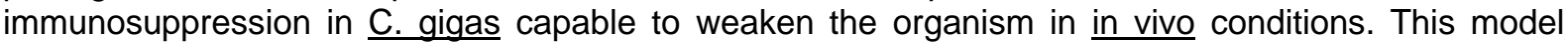
could be suitable for studying interactions between host/pathogen in other models. It would also be interesting to study the expression of the same genes after a sub-lethal injection (4.10 ${ }^{6} \mathrm{CFU} /$ animal) of $\mathrm{V}$. splendidus-related strains. Moreover, pollutants could also have an effect on pathogen virulence. Several genes potentially involved in the virulence of these bacterial strains have been identified (Saulnier et al., personal communication). The joint study of host and pathogen response to pollutants would be of interest to identify the conditions needed for a disease to be established.

\section{Acknowledgements}

Dr. J-L. Nicolas is acknowledged for allowing the work at the IFREMER station in Brest (Bretagne, France). The authors would like to thank Dr J-L. Zambonino for his help in understanding REST Software. K. Moreau is acknowledged for his technical assistance. Dr F. Leroux is acknowledged for her help with bacterial strains. The authors gratefully thank $\mathrm{Dr} \mathrm{C}$. Friedman for improving the English of the manuscript. This research was partly supported by the Poitou-Charentes Region. 


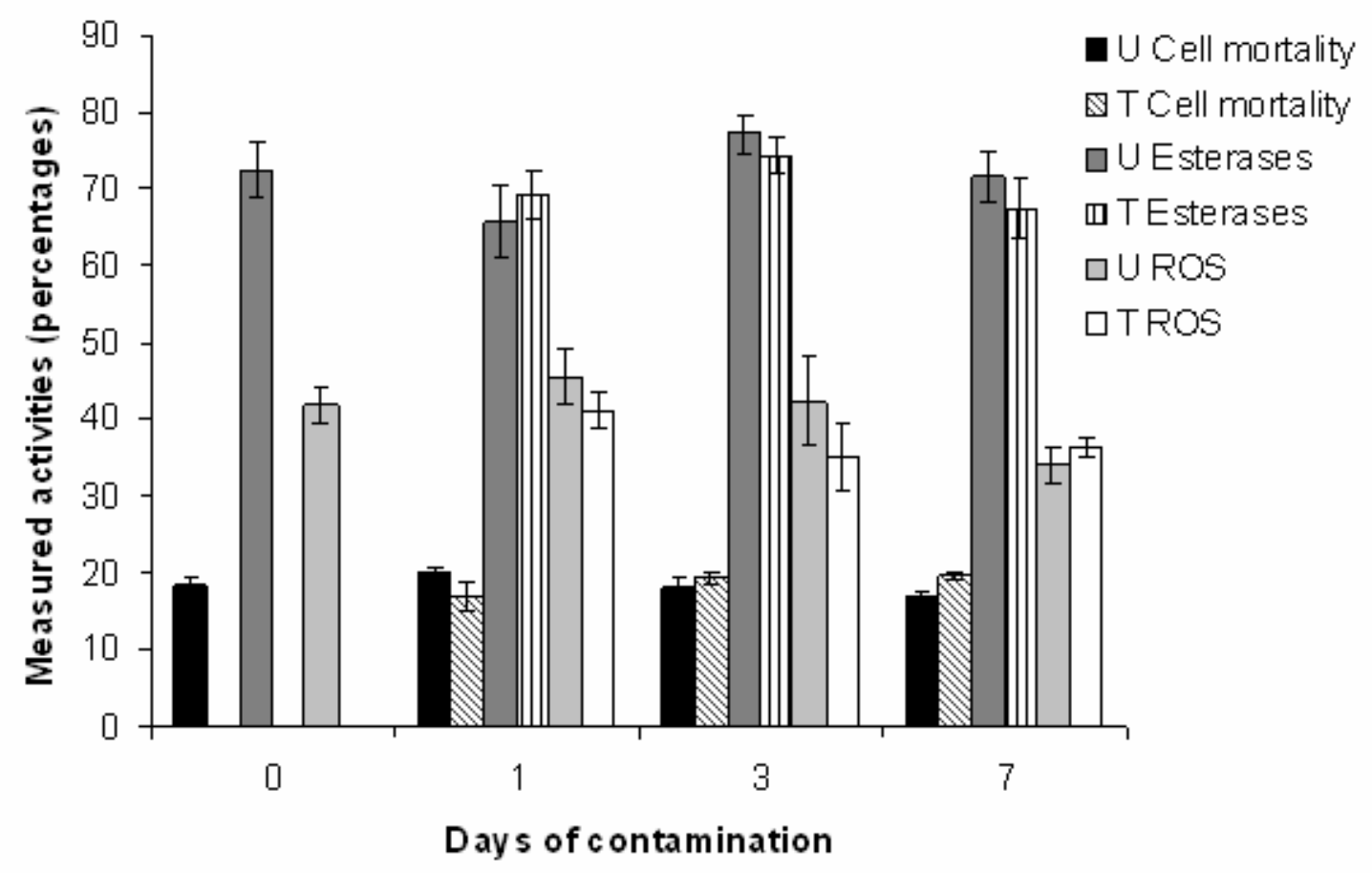

Figure 1: hemocyte parameter results obtained after pooling results from three replicates of the in vivo pesticide contamination (4 pools per replicate). U: untreated oysters, $\mathrm{T}$ : treated oysters. ROS $=$ Reactive Oxygen Species. Means \pm standard errors are presented. $\mathrm{N}=12$ replicates. 

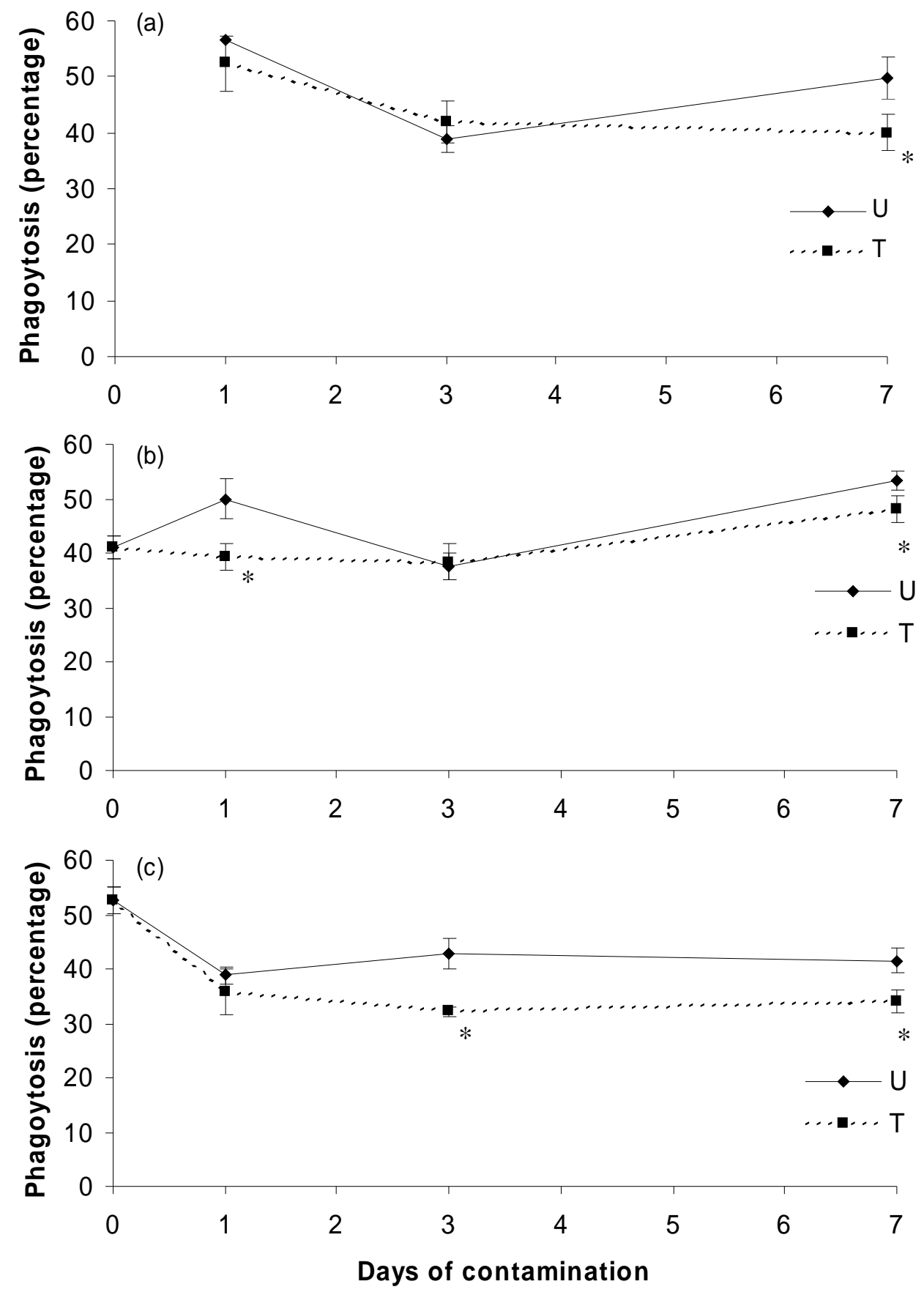

Figure 2: phagocytosis percentages obtained for each of the three in vivo pesticide contamination experiments. U: untreated oysters, T: treated oysters. (a): experiment 1; (b): experiment 2; (c): experiment 3. Means \pm standard errors are presented. $N=4$ replicates for each experiment. *: $p<0.05$. 


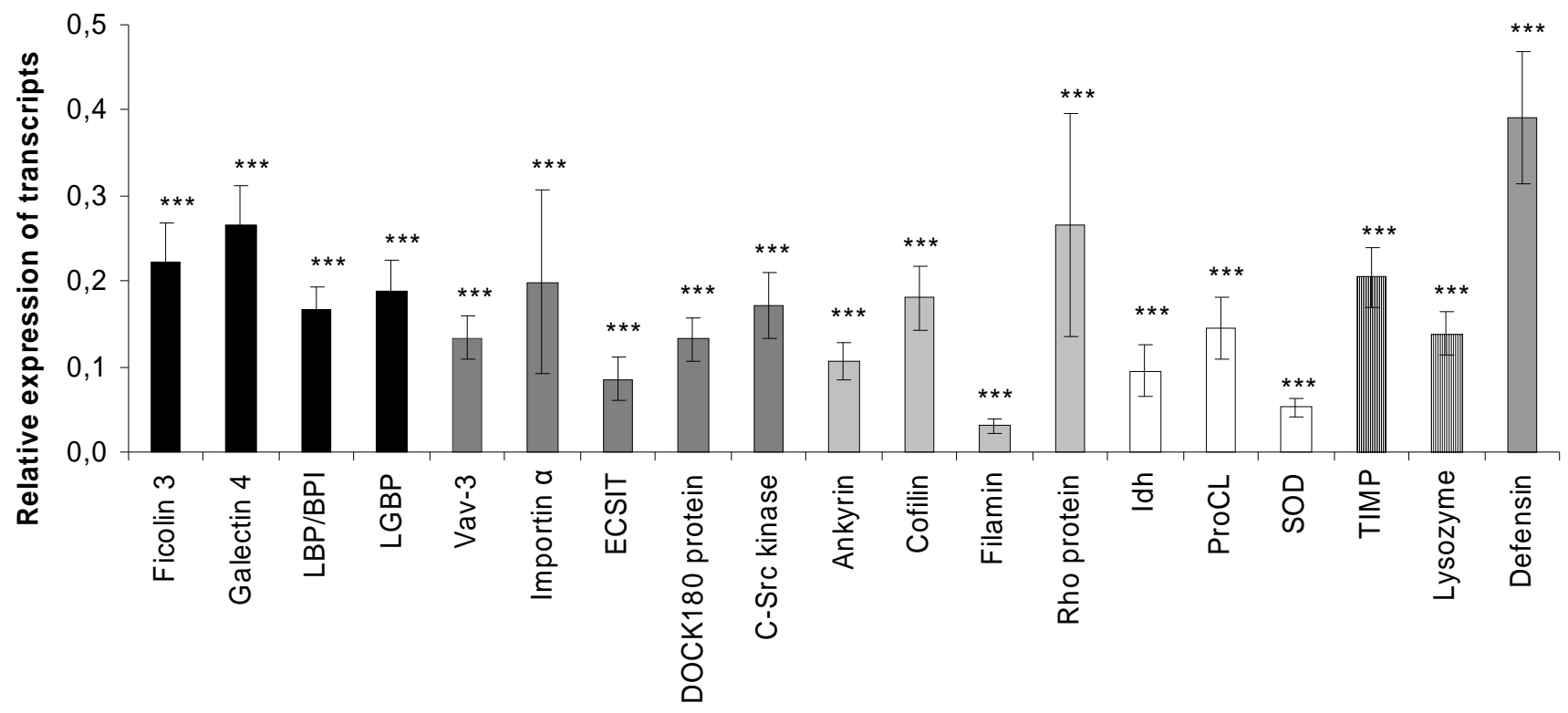

Genes

Figure 3: relative expression of the 19 gene transcripts (normalised to elongation factor I) in pesticide exposed oysters compared to controls after seven days of contamination. RNA was extracted from hemocytes of 20 oysters for each condition. $\mathrm{N}=3$ intra-experimental replicates. Standard error is presented. Value $<0.5$ show a significant decrease of relative expression of transcripts in treated oysters $(T)$ compared to untreated oysters $(U)$. All histograms presented a value $<1 \quad(p<0.001)$. See Table 1 for the category of the genes. 


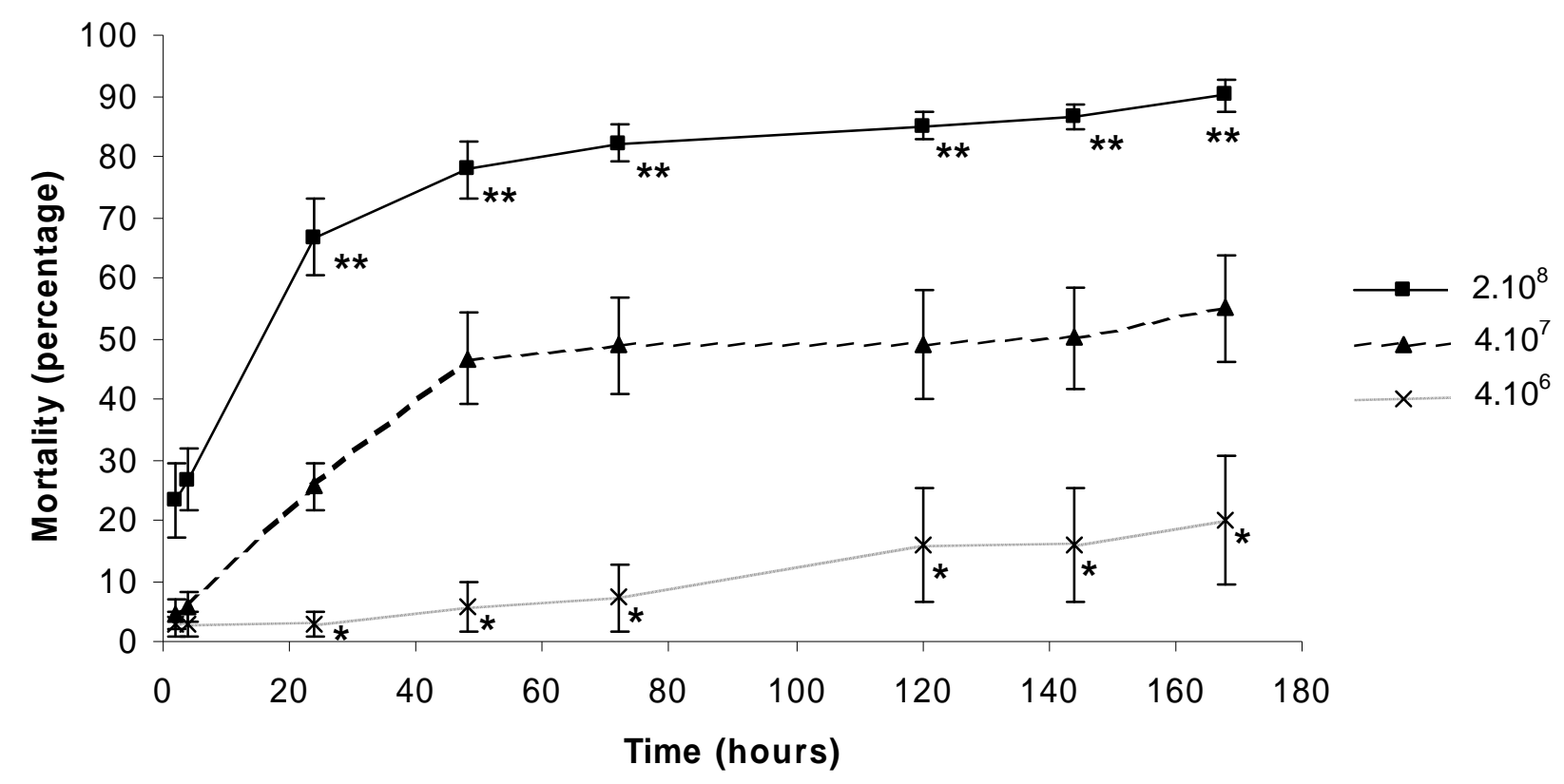

Figure 4: mortality percentages induced by several concentrations of LGP31+LGP32 strains $\left(2.10^{8}\right.$, $4.10^{7}$. and $4.10^{6}$ ) at several post-injection times (2h, $4 \mathrm{~h}, 24 \mathrm{~h}, 48 \mathrm{~h}, 72 \mathrm{~h}, 120 \mathrm{~h}, 144 \mathrm{~h}$ and $\left.168 \mathrm{~h}\right) . \mathrm{N}=6$ replicates. Standard error is presented. *: $p<0.05 ;{ }^{* *}: p<0.01$. 


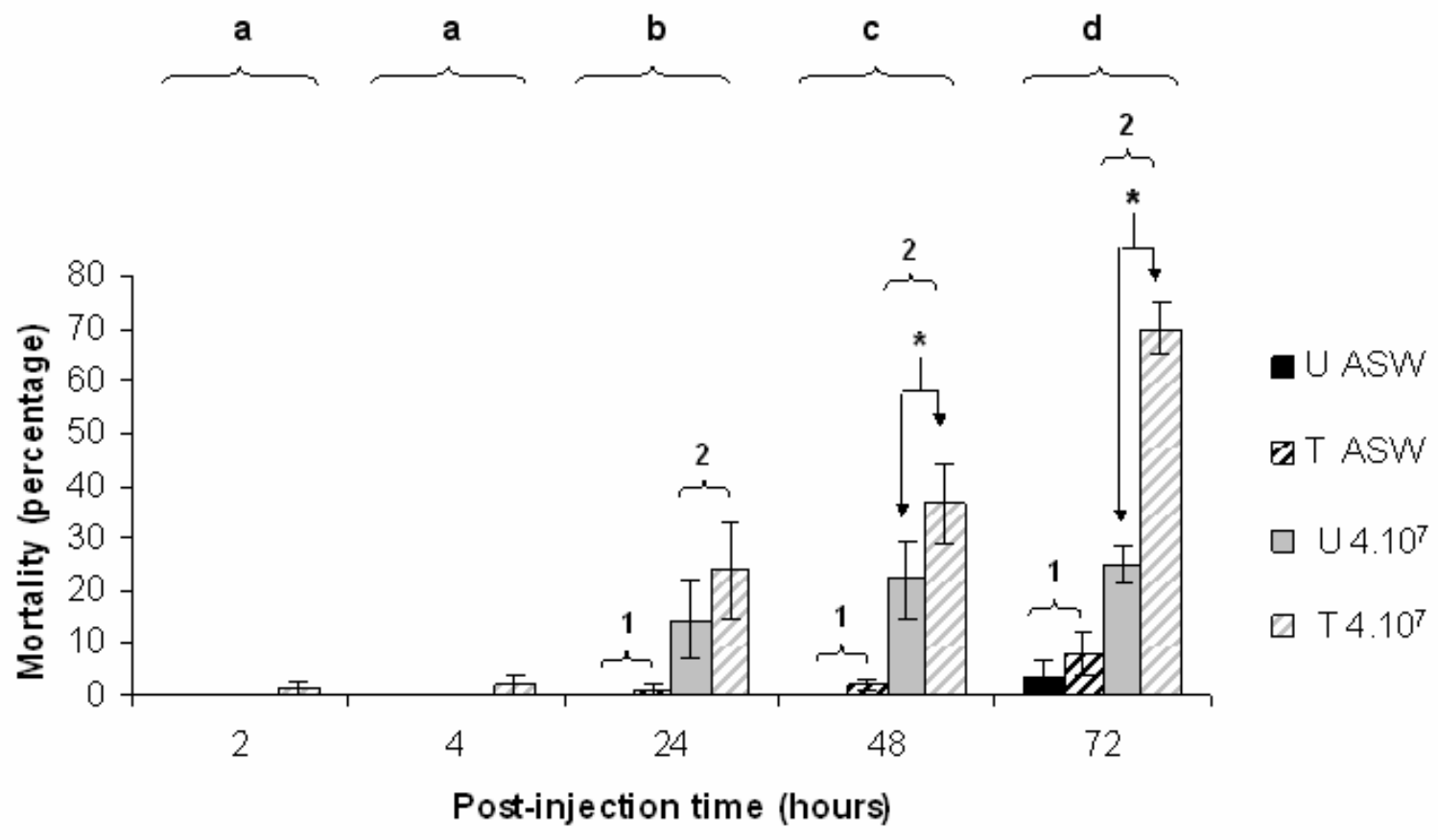

Figure 5: mortality (percent) obtained after injection of artificial seawater or $4.10^{7} \mathrm{CFU} /$ oyster in seven day controls and pesticide exposed oysters. $\mathrm{N}=2$ replicates. Bars represent standard error. * represents a difference between $U$ (untreated oysters) and $T$ (treated oysters) $(U<T, p<0.05)$. Numbers 1 and 2 represent a difference between ASW and $4.10^{7}(1<2, p<0.05)$. Letters $a, b, c$ and $d$ represent a difference between post-injection times $(a<b<c<d, p<0.05)$. 


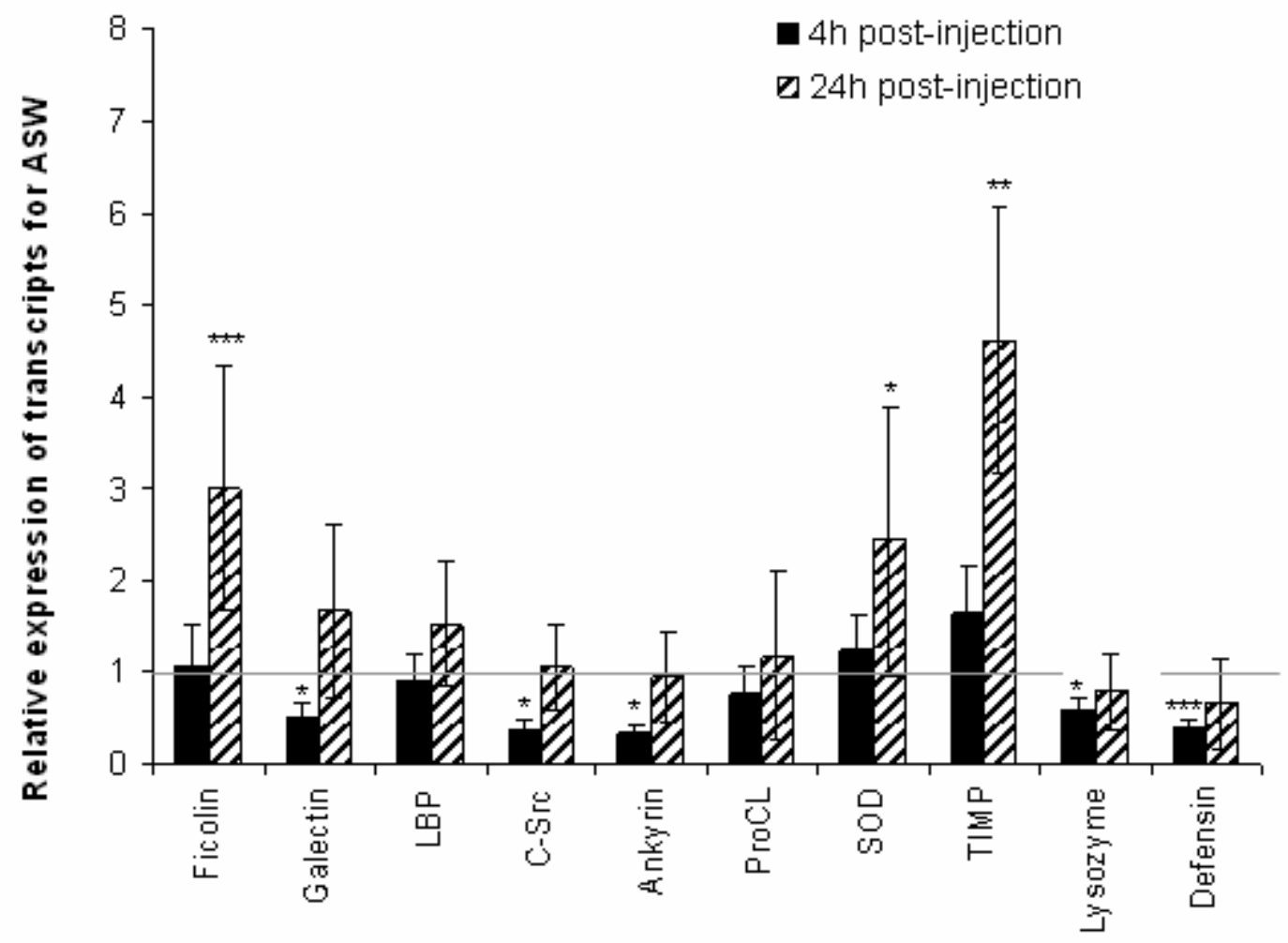

Figure 6: relative expression of the ten gene transcripts (normalised to elongation factor I) in seven days treated oysters injected with ASW compared to untreated oysters injected with ASW $4 \mathrm{~h}$ and $24 \mathrm{~h}$ post-injection. RNA was extracted from hemocytes of 10 oysters for each condition. $\mathrm{N}=3$ intraexperimental replicates. Bars represent standard error. The grey line (value $=1$ ) corresponds to an identical relative expression of transcripts in $U$ (untreated oysters) and $T$ (treated oysters). When statistically different from $1, *: p<0.05 ; * \star: p<0.01 ; * \star *: p<0.001$. 


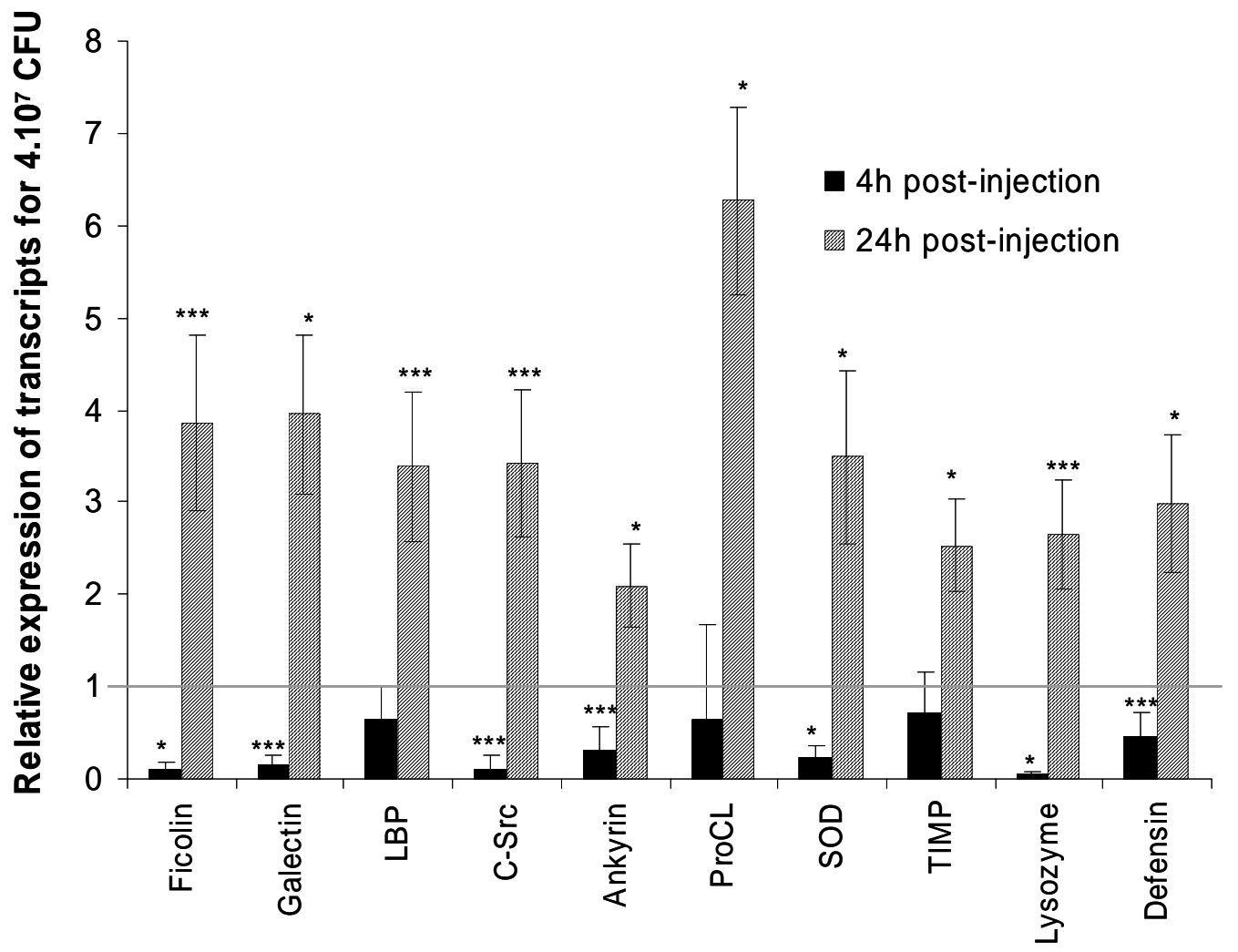

Figure 7: relative expression of the ten gene transcripts (normalised to elongation factor I) in seven days treated oysters injected with $4.10^{7}$ CFU/oyster compared to untreated oysters injected with $4.10^{7}$ $\mathrm{CFU} /$ oyster $4 \mathrm{~h}$ and $24 \mathrm{~h}$ post-injection. RNA was extracted from hemocytes of 10 oysters for each condition. $N=3$ intra-experimental replicates. Standard error is presented. ${ }^{*}: p<0.05 ;{ }^{*}: p<0.01 ; * \star *$ : $p<0.001$. The grey line (value $=1$ ) corresponds to an identical relative expression of transcripts in $U$ (untreated oysters) and T (treated oysters). 


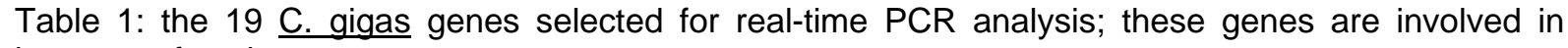
hemocyte functions.

\begin{tabular}{|c|c|c|c|}
\hline Cell signaling & Cytoskeleton proteins & $\begin{array}{l}\text { Post-phagocytosis } \\
\text { degradations and cellular } \\
\text { protection mechanisms }\end{array}$ & Defence mechanisms \\
\hline $\begin{array}{c}\text { Ficolin } \\
\text { Galectin } 4 \\
\text { LBP/BPI protein } \\
\text { LPS/ß-1,3-glucan protein } \\
\text { Vav-3 protein } \\
\text { Importin- } \alpha \\
\text { ECSIT } \\
\text { DOCK } 180 \text { protein } \\
\text { C-Src kinase }\end{array}$ & $\begin{array}{l}\text { Ankyrin } \\
\text { Cofilin } \\
\text { Filamin } \\
\text { Rho protein }\end{array}$ & $\begin{array}{c}\text { Isocitrate deshydrogenase } \\
\text { pro-Cathepsin L } \\
\text { SOD }\end{array}$ & $\begin{array}{l}\text { TIMP } \\
\text { Lysozyme } \\
\text { Defensin }\end{array}$ \\
\hline
\end{tabular}


Table 2: information (primer sequences, GenBank accession numbers and references) related to the 19 genes selected for real-time PCR analysis. Elongation factor I gene was used as reference (Gueguen et al., 2003; Boutet et al., 2004; Huvet et al., 2004; Gueguen et al., 2006).

\begin{tabular}{|c|c|c|c|c|}
\hline Gene & & '’ - 3’ primer sequence & $\begin{array}{c}\text { GenBank } \\
\text { number }\end{array}$ & Reference \\
\hline Ficolin 3 & $\begin{array}{l}\text { Forward } \\
\text { Reverse }\end{array}$ & $\begin{array}{l}\text { Gca aag gct gtg ttc tgt ga } \\
\text { Ctt gta atc cgt cca gtt acg g }\end{array}$ & BQ426875 & Gueguen et al., 2003 \\
\hline Galectin 4 & $\begin{array}{l}\text { Forward } \\
\text { Reverse }\end{array}$ & $\begin{array}{l}\text { Aga aca gac cta cca tgc cac t } \\
\text { Atc cgt ctt gtc cag agc ac }\end{array}$ & BQ426390 & Gueguen et al., 2003 \\
\hline LBP/BPI I & $\begin{array}{l}\text { Forward } \\
\text { Reverse }\end{array}$ & $\begin{array}{l}\text { Acg gca cag aac gga tct ac } \\
\text { Tgg ttg aca tcg ttg ctg ac }\end{array}$ & AY165040 & Gueguen et al., 2003 \\
\hline LPS/ $\beta$-1,3-glucan & $\begin{array}{l}\text { Forward } \\
\text { Reverse }\end{array}$ & $\begin{array}{l}\text { Tgc ggt gaa ctc tga ctt gt } \\
\text { Aat gta gct gtg gga ggt gtg }\end{array}$ & CB617438 & Boutet et al., 2004 \\
\hline $\begin{array}{l}\text { Vav-3 oncogene } \\
\text { homologue }\end{array}$ & $\begin{array}{l}\text { Forward } \\
\text { Reverse }\end{array}$ & $\begin{array}{l}\text { Gcg ttg act ggc tcg tta g } \\
\text { Gca ctc cat ctc gca aag tt }\end{array}$ & BQ427355 & Gueguen et al., 2003 \\
\hline Importin $\alpha$ & $\begin{array}{l}\text { Forward } \\
\text { Reverse }\end{array}$ & $\begin{array}{l}\text { Acg cag cag att gaa cga c } \\
\text { Gca gga gac agt gca gaa tg }\end{array}$ & CB617497 & Boutet et al., 2004 \\
\hline ECSIT & $\begin{array}{l}\text { Forward } \\
\text { Reverse }\end{array}$ & $\begin{array}{l}\text { Gtg tga ttc ccg atg agg ag } \\
\text { Act tgg gca tcc agt aca gc }\end{array}$ & BQ427193 & Gueguen et al., 2003 \\
\hline DOCK 180 protein & $\begin{array}{l}\text { Forward } \\
\text { Reverse }\end{array}$ & $\begin{array}{l}\text { Caa cga ctc cgt tca aca ac } \\
\text { Cgc tgg aaa caa cga aca }\end{array}$ & BQ426954 & Gueguen et al., 2003 \\
\hline c-Src kinase & $\begin{array}{l}\text { Forward } \\
\text { Reverse }\end{array}$ & $\begin{array}{l}\text { Aca aca gga ggc tga agg tg } \\
\text { Gtg tgg cgt gtt tca tcg t }\end{array}$ & BQ426966 & Gueguen et al., 2003 \\
\hline Ankyrine brank-2 & $\begin{array}{l}\text { Forward } \\
\text { Reverse }\end{array}$ & $\begin{array}{l}\text { Gtt cgg agc taa cgt gaa cc } \\
\text { Tag ctg gac gat cag gga gt }\end{array}$ & BQ426701 & Gueguen et al., 2003 \\
\hline Cofilin & $\begin{array}{l}\text { Forward } \\
\text { Reverse }\end{array}$ & $\begin{array}{l}\text { Cgt ggg tga cgg ata gtc tt } \\
\text { Tca gtg gcg tcg tta cac tg }\end{array}$ & BQ426293 & Gueguen et al., 2003 \\
\hline Filamin & $\begin{array}{l}\text { Forward } \\
\text { Reverse }\end{array}$ & $\begin{array}{l}\text { Gtg acc ttt gat ggc tgt ga } \\
\text { Ggt acg aag tcc gtc tcc tg }\end{array}$ & BQ426716 & Gueguen et al., 2003 \\
\hline Rho protein & $\begin{array}{l}\text { Forward } \\
\text { Reverse }\end{array}$ & $\begin{array}{l}\text { Agc aaa gac cag ttc cca ga } \\
\text { Ccc ata atg cca act caa cc }\end{array}$ & BQ426365 & Gueguen et al., 2003 \\
\hline $\begin{array}{c}\text { Isocitrate } \\
\text { dehydrogenase }\end{array}$ & $\begin{array}{l}\text { Forward } \\
\text { Reverse }\end{array}$ & $\begin{array}{l}\text { Ccg acg gaa aga ctg tcg } \\
\text { Ctg gct acc ggg ttt gtg }\end{array}$ & AY551096 & Huvet et al., 2004 \\
\hline $\begin{array}{c}\text { Precursor of Cathepsine } \\
\text { L }\end{array}$ & $\begin{array}{l}\text { Forward } \\
\text { Reverse }\end{array}$ & $\begin{array}{l}\text { Cca gcc aga agc tgt agt cc } \\
\text { Gag cgg aag acg aag cta ga }\end{array}$ & CF369221 & Boutet et al., 2004 \\
\hline SOD-like & $\begin{array}{l}\text { Forward } \\
\text { Reverse }\end{array}$ & $\begin{array}{l}\text { Atg tca cag gaa ccg tcc a } \\
\text { Tcc atg ctg tcc agg tgt ta }\end{array}$ & BQ426796 & Gueguen et al., 2003 \\
\hline TIMP & $\begin{array}{l}\text { Forward } \\
\text { Reverse }\end{array}$ & $\begin{array}{l}\text { Att gcc gtg gtg aga act g } \\
\text { Tag cgt agc agt cgt tcg tg }\end{array}$ & BQ427105 & Gueguen et al., 2003 \\
\hline Lysozyme-like & $\begin{array}{l}\text { Forward } \\
\text { Reverse }\end{array}$ & $\begin{array}{l}\text { Gca gcc gga ttc aac ct } \\
\text { Cgt tgt ggt ctt tgc ttc ac }\end{array}$ & AB179775 & Nakamura et al., unpublished \\
\hline Defensin & $\begin{array}{l}\text { Forward } \\
\text { Reverse }\end{array}$ & $\begin{array}{l}\text { Tgt cct tct gat ggt ttc tgc } \\
\text { Gcc cgc tct aca act aat gg }\end{array}$ & AM050547 & Gueguen et al., 2006 \\
\hline Elongation factor I & $\begin{array}{l}\text { forward } \\
\text { reverse }\end{array}$ & $\begin{array}{l}\text { Acc acc ctg gtg aga tca ag } \\
\text { Acg acg atc gca ttt ctc tt }\end{array}$ & BQ426516 & Gueguen et al., 2003 \\
\hline
\end{tabular}


Table 3: summary of gene expression results obtained with injection of ASW and $4.10^{7} \mathrm{CFU} /$ animal at $4 \mathrm{~h}$ and $24 \mathrm{~h}$ post-injection for the ten genes followed. NS = non significant; arrows = up- or down-regulation.

\begin{tabular}{|c|c|c|c|c|c|c|c|c|c|c|c|}
\hline & & Ficolin & Galectin & LBP & C-Src & Ankyrin & ProCL & SOD & TIMP & Lysozyme & Defensin \\
\hline \multirow{2}{*}{ ASW } & $4 \mathrm{~h}$ & NS & $\nabla$ & NS & $\nabla$ & 7 & NS & NS & NS & $\nabla$ & $\nabla$ \\
\hline & $24 \mathrm{~h}$ & $\Delta$ & NS & NS & NS & NS & NS & $\Delta$ & $\Delta$ & NS & NS \\
\hline \multirow{2}{*}{$4.10^{7}$} & $4 \mathrm{~h}$ & $\nabla$ & $\nabla$ & NS & $\nabla$ & $\nabla$ & NS & $\nabla$ & NS & $\nabla$ & $\nabla$ \\
\hline & $24 \mathrm{~h}$ & $\Delta$ & $\Delta$ & $\Delta$ & $\Delta$ & $\Delta$ & $\Delta$ & $\Delta$ & $\Delta$ & $\Delta$ & $\Delta$ \\
\hline
\end{tabular}




\section{References}

Allam, B., Paillard, C., Auffret, M., Ford, S.E., 2006. Effects of the pathogenic Vibrio tapetis on defence factors of susceptible and non-susceptible bivalve species: II. Cellular and biochemical changes following in vivo challenge. Fish \& Shellfish Immunology 20, 384-397.

Alves, S.R.C., Severino, P.C., Ibbotson, D.P., da Silva, A.Z., Lopes, F.R.A.S., Saenz, L.A., Bainy, A.C.D., 2002. Effects of furadan in the brown mussel Perna perna and in the mangrove oyster Crassostrea rhizophorae. Marine Environmental Research 54, 241-245.

Andrade, R., Alonso, R., Pena, R., Arlucea, J., Arechaga, J., 2003. Localization of importin alpha (Rch1) at the plasma membrane and subcellular redistribution during lymphocyte activation. Chromosoma 112, 87-95.

Ashitani, J., Mukae, H., Nakazato, M., Ihi, T., Mashimoto, H., Kadota, J., Kohno, S., Matsukura, S., 1998. Elevated concentrations of defensins in bronchoalveolar lavage fluid in diffuse panbronchiolitis. The European Respiratory Journal 11, 104-111.

Banerjee, B.D., Koner, B.C., Ray, A., 1996. Immunotoxicity of pesticides: perspectives and trends. Indian Journal of Experimental Biology 34, 723-733.

Banerjee, B.D., Seth, V., Ahmed, R.S., 2001. Pesticide-induced oxidative stress: perspectives and trends. Reviews in Environmental Health 16, 1-40.

Bouilly, K., Bonnard, M., Gagnaire, B., Renault, T., Lapegue, S., 2007. Impact of Diuron on Aneuploidy and Hemocyte Parameters in Pacific Oyster, Crassostrea gigas. Archives of Environmental Contamination and Toxicology 52, 58-63.

Boutet, I., Tanguy, A., Moraga, D., 2004. Response of the Pacific oyster Crassostrea gigas to hydrocarbon contamination under experimental conditions. Gene 329, 147-157.

Breittmayer, J.P., Woaye, C., Zsurger, N., 1984. Effect of cadmium on mercury uptake by mussels (Mytilus edulis). Journal de la Recherche Océanographique 9, 66-68.

Canesi, L., Ciacci, C., Betti, M., Scarpato, A., Citterio, B., Pruzzo, C., Gallo, G., 2003. Effects of PCB congeners on the immune function of Mytilus hemocytes: alterations of tyrosine kinasemediated cell signaling. Aquatic Toxicology 63, 293-306.

Canesi, L., Scarpato, A., Betti, M., Ciacci, C., Pruzzo, C., Gallo, G., 2002. Bacterial killing by mytilus hemocyte monolayers as a model for investigating the signaling pathways involved in mussel immune defence. Marine Environmental Research 54, 547-551.

Cheng, T.C., 1981. Bivalves, In:Ratcliffe, N.A., Rowley, A.F. (Eds), Invertebrate Blood Cells I. Academic Press, London, pp. 233-299.

Chimini, G., Chavrier, P., 2000. Function of Rho family proteins in actin dynamics during phagocytosis and engulfment. Nature Cell Biology 2, 191-196.

Chou, H.-Y., Chang, S.-J., Lee, H.-Y., Chiou, Y.-C., 1998. Preliminary evidence for the effect of heavy metal cations on the susceptibility of Hard Clam (Meretrix lusoria) to clam birnavirus infection. Fish Pathology 33, 213-219.

Chu, F.L., Volety, A.K., Hale, R.C., Huang, Y., 2002. Cellular responses and disease expression in oysters (Crassostrea virginica) exposed to suspended field contaminated sediments. Marine Environmental Research 53, 17-35.

Colosio, C., Birindelli, S., Corsini, E., Galli, C.L., Maroni, M., 2005. Low level exposure to chemicals and immune system. Toxicology and Applied Pharmacology 207, 320-328.

Cote, J.F., Vuori, K., 2002. Identification of an evolutionarily conserved superfamily of DOCK180related proteins with guanine nucleotide exchange activity. Journal of Cell Science 115, 49014913.

Dive, C., Watson, J.V., Workman, P., 1990. Multiparametric analysis of cell membrane permeability by two colour flow cytometry with complementary fluorescent probes. Cytometry 11, 244-52.

Dong, Z., Katar, M., Linebaugh, B.E., Sloane, B.F., Berk, R.S., 2001. Expression of cathepsins B, D and $L$ in mouse corneas infected with Pseudomonas aeruginosa. European Journal of Biochemistry 268, 6408-6416.

Faust, M., Altenburger, R., Backhaus, T., Blanck, H., Boedeker, W., Gramatica, P., Hamer, V., Scholze, M., Vighi, M., Grimme, L.H., 2001. Predicting the joint algal toxicity of multicomponent s-triazine mixtures at low-effect concentrations of individual toxicants. Aquatic Toxicology 56, 13-32.

Fournier, M., Cyr, D., Blakley, B., Boermans, H., Brousseau, P., 2000. Phagocytosis as a biomarker of immunotoxicity in wildlife species exposed to environmental xenobiotics. American Zoologist 40, 412-420.

Fujikawa, K., Miletic, A.V., Alt, F.W., Faccio, R., Brown, T., Hoog, J., Fredericks, J., Nishi, S., Mildiner, S., Moores, S.L., Brugge, J., Rosen, F.S., Swat, W., 2003. Vav1/2/3-null mice define an 
essential role for Vav family proteins in lymphocyte development and activation but a differential requirement in MAPK signaling in T and B cells. Journal of Experimental Medicine $198,1595-1608$

Gagnaire, B., Renault, T., Bouilly, K., Lapegue, S., Thomas-Guyon, H., 2003. Study of atrazine effects on Pacific oyster, Crassostrea gigas, haemocytes. Current Pharmaceutical Design 9, 193-199.

Gagnaire, B., Thomas-Guyon, H., Burgeot, T., Renault, T., 2006. Pollutant effects on Pacific oyster, Crassostrea gigas (Thunberg), hemocytes: screening of 23 molecules using flow cytometry. Cell Biology and Toxicology 22, 1-14.

Gagnaire, B., Thomas-Guyon, H., Renault, T., 2004. In vitro effects of cadmium and mercury on Pacific oyster, Crassostrea gigas (Thunberg), haemocytes. Fish \& Shellfish Immunology 16, 501-512.

Galloway, T.S., Depledge, M.H., 2001. Immunotoxicity in invertebrates: measurement and ecotoxicological relevance. Ecotoxicology 10, 5-23.

Gay, M., Berthe, F.C., Le Roux, F., 2004a. Screening of Vibrio isolates to develop an experimental infection model in the Pacific oyster Crassostrea gigas. Diseases of Aquatic Organisms 59, 49-56.

Gay, M., Renault, T., Pons, A.M., Le Roux, F., 2004b. Two Vibrio splendidus related strains collaborate to kill Crassostrea gigas: taxonomy and host alterations. Diseases of Aquatic Organisms 62, 65-74.

Ge, N.N., Brodie, S.A., Tinling, S.P., Brodie, H.A., 2004. The effects of superoxide dismutase in gerbils with bacterial meningitis. Otolaryngology - Head and Neck Surgery 131, 563-572.

Gueguen, Y., Cadoret, J.P., Flament, D., Barreau-Roumiguiere, C., Girardot, A.L., Garnier, J., Hoareau, A., Bachere, E., Escoubas, J.M., 2003. Immune gene discovery by expressed sequence tags generated from hemocytes of the bacteria-challenged oyster, Crassostrea gigas. Gene 303, 139-145.

Gueguen, Y., Herpin, A., Aumelas, A., Garnier, J., Fievet, J., Escoubas, J.M., Bulet, P., Gonzalez, M., Lelong, C., Favrel, P., Bachere, E., 2006. Characterization of a defensin from the oyster Crassostrea gigas: Recombinant production, folding, solution structure, antimicrobial activities and gene expression. Journal of Biological Chemistry 281, 313-323.

Harvell, C.D., Kim, K., Burkholder, J.M., Colwell, R.R., Epstein, P.R., Grimes, D.J., Hofmann, E.E., Lipp, E.K., Osterhaus, A.D., Overstreet, R.M., Porter, J.W., Smith, G.W., Vasta, G.R., 1999. Emerging marine diseases - climate links and anthropogenic factors. Science 285, 1505-1510.

Haslett, C., Savill, J.S., Meagher, L., 1989. The neutrophil. Current Opinion in Immunology 2, 10-18.

Hu, K.J., Leung, P.C., 2004. Shrimp cathepsin L encoded by an intronless gene has predominant expression in hepatopancreas, and occurs in the nucleus of oocyte. Comparative Biochemistry and Physiology Part B: Biochemistry \& Molecular Biology 137, 21-33.

Huvet, A., Daniel, J.-Y., Quere, C., Dubois, S., Prudence, M., Van Wormhoudt, A., Sellos, D., Samain, J.-F., Moal, J., 2003. Tissue expression of two [alpha]-amylase genes in the Pacific oyster Crassostrea gigas. Effects of two different food rations. Aquaculture 228, 321-333.

Huvet, A., Herpin, A., Degremont, L., Labreuche, Y., Samain, J.F., Cunningham, C., 2004. The identification of genes from the oyster Crassostrea gigas that are differentially expressed in progeny exhibiting opposed susceptibility to summer mortality. Gene 343, 211-220.

Jepson, P.D., Bennett, P.M., Deaville, R., Allchin, C.R., Baker, J.R., Law, R.J., 2005. Relationships between polychlorinated biphenyls and health status in harbor porpoises (Phocoena phocoena) stranded in the United Kingdom. Environmental Toxicology and Chemistry 24, 23848.

Kim, S.Y., Park, J.W., 2003. Cellular defense against singlet oxygen-induced oxidative damage by cytosolic NADP+-dependent isocitrate dehydrogenase. Free Radical Research 37, 309-316.

Kopp, E., Medzhitov, R., Carothers, J., Xiao, C., Douglas, I., Janeway, C.A., Ghosh, S., 1999. ECSIT is an evolutionarily conserved intermediate in the Toll/IL-1 signal transduction pathway. Genes \& Development 13, 2059-2071.

Lambert, S., Bennett, V., 1993. From anemia to cerebellar dysfunction. A review of the ankyrin gene family. European Journal of Biochemistry 211, 1-6.

Lee, K.H., Meuer, S.C., Samstag, Y., 2000. Cofilin: a missing link between T cell co-stimulation and rearrangement of the actin cytoskeleton. European Journal of Immunology 30, 892-899.

Léonard, S.: Réseau Régional de suivi de la qualité des eaux vis-à-vis des produits phytosanitaires. In: GRAP, R.d. (Ed.). Fédération régionale de défense contre les organismes nuisibles de Poitou-Charentes, 2002, pp. 73. 
Mitta, G., Galinier, R., Tisseyre, P., Allienne, J.F., Girerd-Chambaz, Y., Guillou, F., Bouchut, A., Coustau, C., 2005. Gene discovery and expression analysis of immune-relevant genes from Biomphalaria glabrata hemocytes. Developmental \& Comparative Immunology 29, 393-407.

Montagnani, C., Le Roux, F., Berthe, F., Escoubas, J.-M., 2001. Cg-TIMP, an inducible tissue inhibitor of metalloproteinase from the Pacific oyster Crassostrea gigas with a potential role in wound healing and defense mechanisms. FEBS Letters 500, 64-70.

Munaron, D., Dubernet, J.F., Delmas, F., Stanisiere, J.Y., Scribe, P., 2006. Assessment of the quantities of herbicides and nutrients brought down by the river Charente to the coast and modelling of the dispersion of atrazine in the Marennes-Oleron bay. Cahiers De Biologie Marine 47, 85-92.

Parry, H.E., Pipe, R.K., 2004. Interactive effects of temperature and copper on immunocompetence and disease susceptibility in mussels (Mytilus edulis). Aquatic Toxicology 69, 311-325.

Pfaffl, M.W., 2001. A new mathematical model for relative quantification in real-time RT-PCR. Nucleic Acids Research 29, 2002-2007.

Pfaffl, M.W., Horgan, G.W., Dempfle, L., 2002. Relative expression software tool (REST) for groupwise comparison and statistical analysis of relative expression results in real-time PCR. Nucleic Acids Research 30, 1-10.

Pipe, R.K., Coles, J.A., 1995. Environmental contaminants influencing immune function in marine bivalve molluscs. Fish \& Shellfish Immunology 5, 581-595.

Rothe, G., Oser, A., Valet, G., 1988. Dihydrorhodamine 123: a new flow cytometric indicator for respiratory burst activity in neutrophil granulocytes. Naturwissenschaften 75, 354-355.

Russo, J., Lagadic, L., 2004. Effects of environmental concentrations of atrazine on hemocyte density and phagocytic activity in the pond snail Lymnaea stagnalis (Gastropoda, Pulmonata). Environmental Pollution 127, 303-311.

Snieszko, S.F., 1974. The effects of environmental stress on outbreaks of infectious diseases of fishes. Journal of Fish Biology 6, 197-208.

Suzuki, T., Kono, H., Hirose, N., Okada, M., Yamamoto, T., Yamamoto, K., Honda, Z., 2000. Differential involvement of Src family kinases in Fc gamma receptor-mediated phagocytosis. Journal of Immunology 165, 473-482.

Tanguy, A., Boutet, I., Laroche, J., Moraga, D., 2005. Molecular identification and expression study of differentially regulated genes in the Pacific oyster Crassostrea gigas in response to pesticide exposure. The Febs Journal 272, 390-403.

Tanguy, A., Guo, X., Ford, S.E., 2004. Discovery of genes expressed in response to Perkinsus marinus challenge in Eastern (Crassostrea virginica) and Pacific (C. gigas) oysters. Gene 338, 121-131.

Van der Flier, A., Sonnenberg, A., 2001. Structural and functional aspects of filamins. Biochimica and Biophysica Acta - Molecular Cell Research 1538, 99-117.

Wong, S., Fournier, M., Coderre, D., Banska, W., Krzystyniak, K., 1992. Environmental immunotoxicology, In:Peakall, D. (Eds), Animals Biomarkers as Pollution Indicators. Chapman and Hall, London, pp. 167-189.

Wootton, E.C., Dyrynda, E.A., Pipe, R.K., Ratcliffe, N.A., 2003. Comparisons of PAH-induced immunomodulation in three bivalve molluscs. Aquatic Toxicology 65, 13-25. 